\title{
Identification of Compounds in Commercial Kava Extracts by Gas Chromatography with Electron Ionization High-Resolution Mass Spectrometry
}

\author{
Viorica Lopez-Avila ${ }^{*}$ and George Yefchak
}

Agilent Technologies, Santa Clara, CA 95051, USA

\begin{abstract}
This paper discusses the identification of kava lactones and related compounds by gas chromatography (GC) and quadrupole time-of-flight mass spectrometry (QTOFMS) with an electron ionization source. Three herbal preparations from different sources were analyzed by both GC-low-resolution MS and GC-high-resolution MS. The exact mass measurements generated with a research QTOFMS with mass accuracies in the low ppm range were combined with the isotope abundance ratios to confirm the presence of kava lactones and to identify additional compounds present in the Kava extracts. Although the availability of standards is of upmost importance to unequivocally confirm compound identities, the combination of accurate mass $(<3 \mathrm{ppm}$ average mass accuracy), isotope abundance ratios, high resolution $(>10,000)$ and literature information on the approximate composition of the herbal extracts provides a powerful analytical tool to help identify organic compounds in herbal extracts.
\end{abstract}

\section{INTRODUCTION}

Kava (Piper methysticum) is a perennial shrub from the Piperaceae family that grows throughout South Pacific. Kava root is known to contain $43 \%$ starch, $20 \%$ fiber, $12 \%$ water, $3.2 \%$ sugars, $3.6 \%$ proteins, $3.2 \%$ minerals, and up to $20 \%$ kava lactones [1]. Kava has been used for over 3000 years as a relaxing beverage in Vanuatu, Samoa, Tonga, and Fiji, and in Vanuatu, in particular, there are establishments that serve thousands of fresh Kava juice beverages daily [2]. In Europe, Kava has been used for about 40 years in a form of highly concentrated extracts of dry root generated by using acetone or alcohol. The extraction with organic solvents generates a sticky paste which may not contain the same compounds that are extracted with water, which is the traditional procedure by natives of the South Pacific. Details and the pharmacology as well as the biological activity of Kava can be found elsewhere [3].

Several analytical techniques including thin-layer chromatography $[1,4,5]$, gas chromatography (GC) lowresolution mass spectrometry (MS) or GC/MS) [4, 6-9], GC with flame ionization detection [9, 10], high-performance liquid chromatography (HPLC) with ultraviolet detection [10] or atmospheric pressure chemical ionization tandem MS [11] or electrospray MS [12, 13], micellar electrokinetic chromatography [14], nuclear magnetic resonance (NMR) spectroscopy $[5,9,11]$, and near-infrared reflectance spectroscopy [15] have been used to characterize Kava. High-resolution MS (using a double focusing system with EB geometry) and NMR ( ${ }^{1} \mathrm{H} 500 \mathrm{MHz}$ and ${ }^{13} \mathrm{C}$ at $125 \mathrm{MHz}$ ) have also been reported [9] for the identification of a few piperidine alkaloids (i.e., pipermethystine, $3 \alpha, 4 \alpha$-epoxy-5 $\beta$ pipermethystine, and awaine) in aerial parts of Kava plant

*Address correspondence to this author at the Agilent Technologies, Santa Clara, CA 95051, USA; Tel: 01408 5532709; Fax: 01408 5533677;

E-mail: viorica_lopez-avila@agilent.com because some herbal supplements may contain ingredients from aerial stem peelings. In another report on use of highresolution MS, Warburton and Bristow [16] used Fourier Transform ion cyclotron resonance MS to characterize six kava lactones extracted from kava root with acetone and then separated by HPLC. A combination of sustained offresonance radiation collision induced dissociation (SORICID) and infrared multiphoton dissociation (IRMPD) has enabled the confirmation of six lactones in kava extracts [16].

Lopez-Avila and Benedicto [6] used GC/MS to identify kava lactones in Kava extracts generated using supercritical fluid extraction with modified carbon dioxide and Cheng and coworkers [7] used methane chemical ionization GC/MS to identify the kava lactones in steam distillates and aqueous extracts of commercial Piper methysticum. The extraction efficiency of water, which is the traditional method for preparing the kava beverage, was typically $5-10 \%$ of that obtained by extraction with an organic solvent [7]. Major compounds identified in Kava extracts by low-resolution GC/MS include kava lactones like kavain, dihydro-and dehydrokavains, yangonin and tetrahydroyangonin, methysticin and dihydromethysticin $[2,6]$. The root is also known to contain Flavokavins $\mathrm{A}$ and $\mathrm{B}$, pipermethystine, cepharadione A, cinnamalketone, and methylene dioxy-3, 4-cinnamalketone [3]. Bornyl cinnamate and a series of hydroxylated compounds resulting from the decarbonylation of the lactones have also been identified in kava resin by methane chemical ionization GC/MS [7]. Cheng et al. [7] actually synthesized bornyl cinnamate from cinnamoyl chloride and borneol and confirmed that the peak present in the kava resin was indeed bornyl cinnamate. In all, as many as 18 different kava lactones have been reported in Piper methysticum by the various procedures mentioned above [17].

This study reports the identification of kava lactones, and a few compounds similar to Flavokavins $A$ and $B$ in commercial Kava preparations using both low-resolution 
Table 1. Identification of Kava Extracts from Commercial Sources

\begin{tabular}{|c|c|c|c|}
\hline Extract & Source & Total Kava Lactones (mg/capsule) & Other Ingredients \\
\hline \hline KV1 & Gaia Herbs & 75 & Lecithin, glycerin, cellulose \\
\hline KV2 & Herb Pharm & 60 & Acacia tree gum, maltodextrin, cellulose, Mg stearate, silica \\
\hline KV3 & Eclectic Institute & 76.5 & N/A \\
\hline
\end{tabular}

GC/MS with electron ionization (EI) and high-resolution MS using a QTOFMS with an EI source.

\section{EXPERIMENTAL}

\subsection{Materials}

The composition of the three Kava extracts, identified as KV1 (Gaia Herbs, Brevard, NC, USA), KV2 (Herb Pharm, Williams, OR, USA), and KV3 (Eclectic Institute, Sandy, OR, USA), and details given by the manufacturers are shown in Table 1. Progesterone (USP, Rockville, MD, USA) was used as internal standard for GC/MS analysis. Known amounts of each Kava capsule were dissolved in dichloromethane (ACS spectrophotometric grade) and filtered through a $0.2 \mu \mathrm{m}$ GHP Acrodisk (Pall Gelman Labs, East Hills, NY, USA) prior to GC/MS analysis. Each extract was spiked with $5 \mu \mathrm{L}$ of a stock solution of progesterone in dichloromethane at $1 \mathrm{mg} / \mathrm{mL}$ immediately prior to analysis.

\subsection{Instrumentation}

\subsubsection{GC-Electron Ionization Low-Resolution MS Analysis}

GC/MS analyses were performed on an 6890 gas chromatograph interfaced to an Agilent 5973 mass spectrometer with an electron ionization (EI) source and equipped with an Agilent autoinjector and the Agilent ChemStation for data processing (Agilent Technologies, Santa Clara, CA, USA). Samples were introduced via a $30 \mathrm{~m}$ x $0.25 \mathrm{~mm}$ id x $0.25 \mu \mathrm{m}$ film thickness HP-5MS capillary column also from Agilent Technologies. The oven temperature was held at $40^{\circ} \mathrm{C}$ for $4 \mathrm{~min}$, then was programmed to a final temperature of $275^{\circ} \mathrm{C}$ at $8^{\circ} \mathrm{C} / \mathrm{min}$, where it was held for $8.5 \mathrm{~min}$. Helium was used as carrier gas at a flow rate of $1 \mathrm{~mL} / \mathrm{min}$. The injector temperature was $280^{\circ} \mathrm{C}$ and the $\mathrm{GC} / \mathrm{MS}$ transfer line temperature was $275^{\circ} \mathrm{C}$. The injector fitted with a double tapered liner was set in splitless mode for $2 \mathrm{~min}$ after the injection (purge flow was $50 \mathrm{~mL} / \mathrm{min}$ ). The electron energy was set at $70 \mathrm{eV}$ and the electron multiplier voltage was set at $1529 \mathrm{~V}$. Spectral data were acquired at a rate of 9 scans/sec and the scanning range was $\mathrm{m} / \mathrm{z} 50$ to 600 . The instrument was tuned daily with perfluorotributylamine introduced directly into the EI source via the calibration gas valve.

\subsubsection{GC-Electron Ionization QTOFMS Analysis}

The experimental mass measurements were collected with a research GC/QTOF MS instrument comprising an Agilent $6890 \mathrm{GC}$, an EI source from an Agilent 5975 model

Table 2. Compounds Identified in the Kava Extracts by GC/QTOFMS

\begin{tabular}{|c|c|c|c|c|c|c|c|c|}
\hline \multirow{2}{*}{$\begin{array}{l}\text { Compound } \\
\text { No. }\end{array}$} & \multirow{2}{*}{ Compound Name } & \multirow{2}{*}{$\begin{array}{c}\text { Molecular Ion } \\
\text { Formula (Except for } \\
\text { Compounds C and D) }\end{array}$} & \multirow{2}{*}{$\begin{array}{c}m / z \\
\text { (calc) }\end{array}$} & \multirow{2}{*}{$\begin{array}{c}m / z \\
\text { (experim) }\end{array}$} & \multirow{2}{*}{$\begin{array}{c}\text { Mass } \\
\text { Accuracy }^{\mathrm{a}} \\
(\mathrm{ppm}) / \text { score }^{\mathrm{b}}\end{array}$} & \multicolumn{3}{|c|}{ Relative Intensity ${ }^{c}$} \\
\hline & & & & & & KV1 & KV2 & KV3 \\
\hline 1 & 7, 8 Dihydrokavain & $\mathrm{C}_{14} \mathrm{H}_{16} \mathrm{O}_{3}$ & 232.1094 & 232.1077 & $7.4 / 83.7$ & 2.13 & 0.75 & 1.60 \\
\hline 2 & Kavain & $\mathrm{C}_{14} \mathrm{H}_{14} \mathrm{O}_{3}$ & 230.0937 & 230.0931 & $2.7 / 95.1$ & 1.57 & 0.50 & 0.58 \\
\hline 3 & 5, 6-Dehydrokavain & $\mathrm{C}_{14} \mathrm{H}_{12} \mathrm{O}_{3}$ & 228.0781 & 228.0778 & $1.5 / 93.9$ & 0.71 & 0.18 & 0.36 \\
\hline 4 & $\begin{array}{c}5,6,7,8- \\
\text { Tetrahydroyangonin }\end{array}$ & $\mathrm{C}_{15} \mathrm{H}_{18} \mathrm{O}_{4}$ & 262.1200 & 262.1190 & $3.7 / 95.4$ & 0.29 & 0.09 & 0.11 \\
\hline 5 & 7, 8-Dihydromethysticin & $\mathrm{C}_{15} \mathrm{H}_{16} \mathrm{O}_{5}$ & 276.0992 & 276.0986 & $2.5 / 97.9$ & 1.23 & 0.32 & 0.90 \\
\hline 6 & Yangonin & $\mathrm{C}_{15} \mathrm{H}_{14} \mathrm{O}_{4}$ & 258.0887 & 258.0884 & $0.9 / 93.7$ & 0.96 & 0.23 & 0.45 \\
\hline 7 & Methysticin & $\mathrm{C}_{15} \mathrm{H}_{14} \mathrm{O}_{5}$ & 274.0836 & 274.0832 & $1.9 / 96.9$ & 0.82 & 0.09 & 0.30 \\
\hline A & Bornyl cinnamate & $\mathrm{C}_{19} \mathrm{H}_{24} \mathrm{O}_{2}$ & 284.1771 & 284.1754 & $5.9 / 69.6$ & 0.20 & 0.03 & 0.31 \\
\hline B & $\begin{array}{l}\text { Dihydroxy-methoxyphenyl- } \\
\text { phenyl-propen-one }\end{array}$ & $\mathrm{C}_{16} \mathrm{H}_{14} \mathrm{O}_{4}$ & 270.0887 & 270.0874 & $4.7 / 86.3$ & 0.16 & $<0.01$ & 0.03 \\
\hline $\mathrm{C}$ & $\begin{array}{l}\text { Hydroxy-dimethoxyphenyl- } \\
\text { 3-phenyl-2-propen-1-one }\end{array}$ & $\mathrm{C}_{17} \mathrm{H}_{15} \mathrm{O}_{4}$ & 283.0965 & 283.0959 & $2.2 / 96.0$ & 0.24 & 0.02 & 0.13 \\
\hline $\mathrm{D}$ & $\begin{array}{l}\text { Hydroxy-dimethoxyphenyl- } \\
\text { 3-methoxyphenyl-2-propen- } \\
\text { 1-one }\end{array}$ & $\mathrm{C}_{18} \mathrm{H}_{17} \mathrm{O}_{5}$ & 313.1071 & 313.1062 & $2.5 / 89.3$ & 0.11 & $<0.01$ & $<0.01$ \\
\hline
\end{tabular}

${ }^{a}$ Mass accuracy is calculated as ppm error where calculated $\mathrm{m} / \mathrm{z}$ is subtracted from the experimental $\mathrm{m} / \mathrm{z}$, divided by the experimental $\mathrm{m} / \mathrm{z}$, and multiplied by $10^{6}$.

${ }^{b}$ Score is calculated from Mass Match, Abundance Match, and Spacing Match by applying the corresponding weighting factors of 100,60 , and 50\%, respectively.

${ }^{\mathrm{c}}$ Relative to progesterone spiked into each extract at the same concentration.

${ }^{\mathrm{d}}$ Tentatively identified as $\mathrm{C}_{17} \mathrm{H}_{16} \mathrm{O}_{4}$ from the (M-H) ion at $m / z 283.0959$.

${ }^{\mathrm{e}}$ Tentatively identified as $\mathrm{C}_{18} \mathrm{H}_{18} \mathrm{O}_{5}$ from the (M-H) ion at $\mathrm{m} / z 313.1062$. 
low-resolution MS and an Agilent 6510 QTOFMS that was upgraded with a $4-\mathrm{GHz}$ data acquisition system. To implement electron ionization, we removed the electrospray source and the first octapole assembly from the QTOFMS and replaced them with the EI source from a 5975 mass spectrometer. The GC conditions were identical to those described above except for a 1-m heated transfer line. The ionization energy in the EI source was $70 \mathrm{eV}$. The collision energy was $20 \mathrm{eV}$ for MS/MS experiments, with nitrogen as the collision gas. The mass axis was calibrated using seven peaks from perfluorotributylamine, and a background phthalate ion at $\mathrm{m} / \mathrm{z} 149.02332$ was used as a real-time reference ("lock mass"). Octafluoronaphthalene (peak at $\mathrm{m} / \mathrm{z}$ 271.9867) was used to establish mass accuracy, resolution and instrument sensitivity. The Agilent MassHunter software was used to generate molecular formulas from the exact mass of the monoisotopic peak and the "Formula Generation" module of the MassHunter algorithm was used to calculate the isotope distribution mass errors and the score values given in Table $\mathbf{2}$.

\section{RESULTS AND DISCUSSION}

\subsection{Identification of Kava Lactones}

In this paper we report on the composition of three Kava extracts in which we have found seven kava lactones and several other trace components. The analytical tools used for this purpose include GC/MS (in both low-resolution and high-resolution MS mode). The seven lactones were easily identified from their GC elution times, which agreed to those published previously [6], and the EI mass spectra.

Fig. (1) shows GC/MS chromatograms (low-resolution MS mode) of three Kava extracts and Table 2 gives the molecular formula, the calculated and experimental $\mathrm{m} / \mathrm{z}$ of the molecular ion, mass accuracy and scores, and the relative intensity of each of the seven lactones to progesterone which was used as internal standard, and a few other compounds identified in the three Kava extracts. The seven lactones were present in all extracts but their levels varied quite a lot (manufacturers claim a total content of 75,60 and $76.5 \mathrm{mg}$ total lactones per capsule for KV1, KV2, and KV3, respectively). The exact concentration of each lactone is not

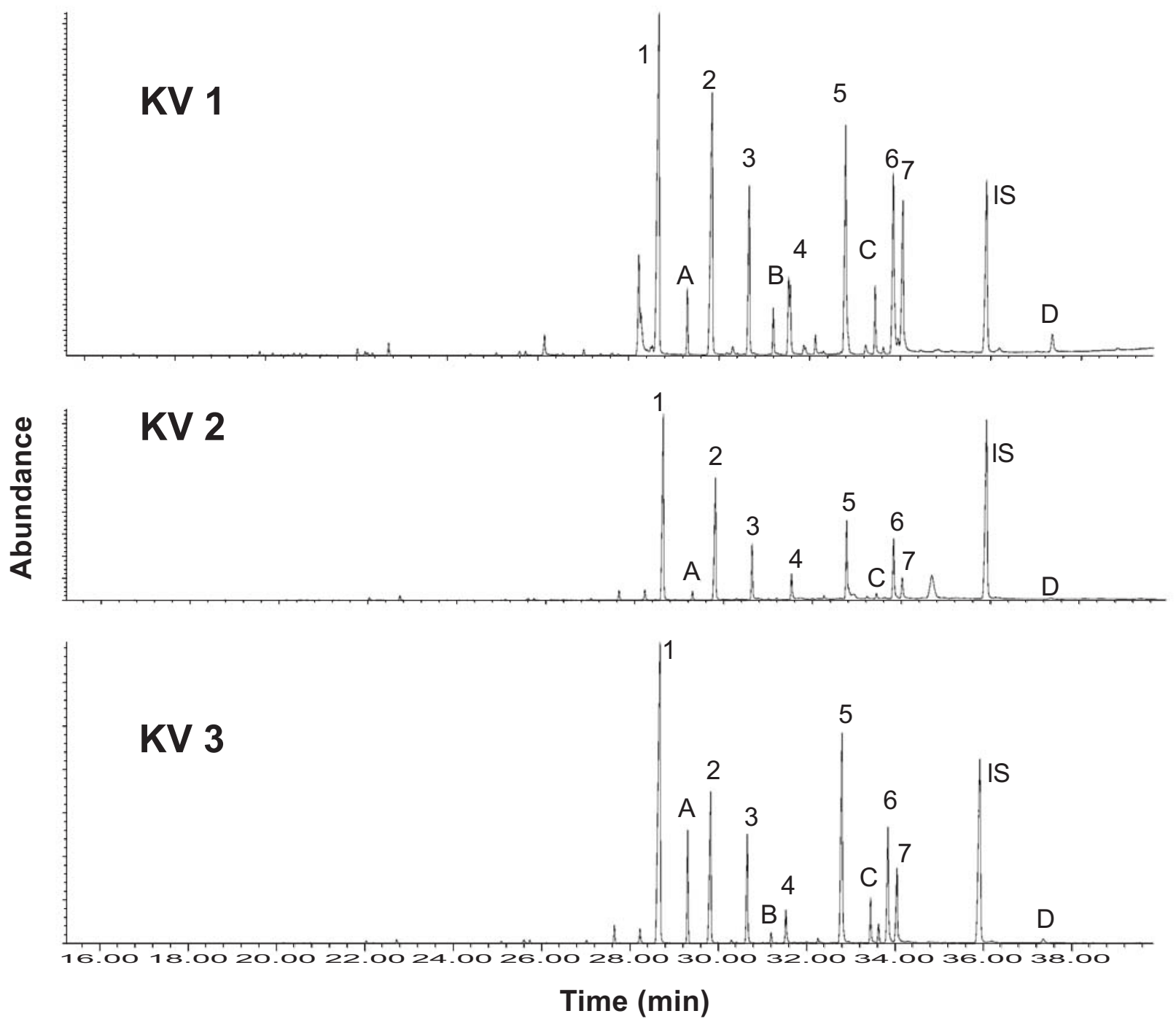

Fig. (1). GC/MS chromatograms (low-resolution MS mode) of three Kava extracts. 
given due to lack of calibration standards. The lowresolution (EI) MS and high-resolution (EI-QTOFMS) mass spectra of each lactone are included in Figs. (A1-A7) in the supplementary material.

The following conclusions can be drawn from analysis of the QTOFMS spectra:

- The intensity of the molecular ion is consistently lower in the QTOFMS spectra than the low-resolution spectra, suggesting that fragmentation takes place as the ion travels through the collision cell despite no voltages were applied to the collision cell.

- $\quad$ Kava lactones with a saturated C-C bond between the phenyl ring and the pyrone ring exhibit molecular ions at lower intensities than those in the corresponding low-resolution spectra, most likely due to the fact that the $\mathrm{C}-\mathrm{C}$ bond breaks easily to form the corresponding tropylium (or substituted tropylium) ions at $\mathrm{m} / \mathrm{z} 91.0545,121.0649$, and 135.0441 for Compounds 1,4 , and 5 , respectively.

- When the $\mathrm{C}=\mathrm{C}$ bond between the phenyl ring and the pyrone ring is conjugated with a $\mathrm{C}=\mathrm{C}$ bond in the position 5-6 of the pyrone ring, the molecular ion is more stable as shown on both the low-resolution and the high-resolution spectra (see Figs. A3, A6 in supplementary material for Compounds 3 and 6 , respectively).

- $\quad$ Compounds 1,4 , and 5 show elimination of methanol from the molecular ions whereas Compounds 2, 3, 6, and 7 show first elimination of $\mathrm{CO}$ which leads to a more stable furan ring.

\subsection{Identification of Compound A}

Low-resolution MS spectrum of Compound A shown in Fig. (2) exhibits ions at $m / z 284,153,131,109,103,77$ and 55. The NIST library search identified this compound as bornyl cinnamate having molecular formula of $\mathrm{C}_{19} \mathrm{H}_{24} \mathrm{O}_{2}$. The QTOFMS data indicate that the ion at $m / z 284.1754$ corresponds to $\mathrm{C}_{19} \mathrm{H}_{24} \mathrm{O}_{2}$, the ion at $m / z 131.0492$, which has a mass error of $0.2 \mathrm{ppm}$ and a score of 98.6 , corresponds to $\mathrm{C}_{9} \mathrm{H}_{7} \mathrm{O}$ (CO$\mathrm{CH}=\mathrm{CH}-\mathrm{C}_{6} \mathrm{H}_{5}$ ), and the ion at $\mathrm{m} / 2103.0542$ corresponds to $\mathrm{C}_{8} \mathrm{H}_{7}$ $\left(\mathrm{CH}=\mathrm{CH}-\mathrm{C}_{6} \mathrm{H}_{5}\right)$. Charge retention on the aromatic side of the molecule with the elimination of the bornyloxy group gives the fragment ion $\mathrm{C}_{9} \mathrm{H}_{7} \mathrm{O}$ at $\mathrm{m} / 2$ 131.0492, which upon elimination of $\mathrm{CO}$ forms the fragment ion $\mathrm{C}_{8} \mathrm{H}_{7}$ at $\mathrm{m} / z$ 103.0542. Other ions in the QTOFMS spectrum of Compound A (see Fig. 2) are fragment ions at $\mathrm{m} / \mathrm{z} 93.0700$ (mass error $1.1 \mathrm{ppm}$, score 97.5) and 121.1013 (mass error $1.3 \mathrm{ppm}$, score 83.0), which account for $\mathrm{C}_{7} \mathrm{H}_{9}$ and $\mathrm{C}_{9} \mathrm{H}_{13}$, respectively, and are likely formed by further fragmentation of the bornyl group. QTOFMS/MS spectrum shown in Fig. (2) confirms that ions at $m / z$ 131.0493, 121.1013, 103.0542, 93.0700, and 77.0385 form from precursor ion at $\mathrm{m} / \mathrm{z}$ 284.1754, which is the molecular ion of Compound A. From the high-resolution data, we concluded that the NIST library search was likely true and, thus, this compound was identified as bornyl cinnamate.

\subsection{Identification of Compound $B$}

Low-resolution MS spectrum of Compound B shown in Fig. (3) exhibits ions at $m / z 270,193,166,138,95$, and 69 and the molecular ion appears to be at $m / z 270$. The NIST library search gave at least two possible hits for this compound having molecular formulas $\mathrm{C}_{16} \mathrm{H}_{14} \mathrm{O}_{4}$ and $\mathrm{C}_{17} \mathrm{H}_{18} \mathrm{O}_{3}$. Molecular formula $\mathrm{C}_{16} \mathrm{H}_{14} \mathrm{O}_{4}$ was retained because it has a calculated $\mathrm{m} / 2270.0887$ and the experimental $\mathrm{m} / \mathrm{z}$ for compound $\mathrm{B}$ of 270.0874 had a mass accuracy of $4.7 \mathrm{ppm}$ and a resolution of 15,822 . Molecular formula $\mathrm{C}_{17} \mathrm{H}_{18} \mathrm{O}_{3}$, which has a calculated $\mathrm{m} / z$ of 270.1250 , was eliminated from consideration because the mass error was 139 $\mathrm{ppm}$. When operated in MS only mode, the mass accuracy of our QTOFMS had consistently been below $3 \mathrm{ppm}$ for octafluoronaphthalene (i.e., ion at $\mathrm{m} / \mathrm{z}$ 271.9867) at levels ranging from $10 \mathrm{pg}$ to $1 \mathrm{ng}$ per injection. When operated in MS/MS mode, the mass accuracy of our QTOFMS had consistently been below $3 \mathrm{ppm}$ for progesterone (i.e., precursor ion at $\mathrm{m} / \mathrm{z} 299.1999$ and product ions at $\mathrm{m} / \mathrm{z} 281.1899,229.1594$, $147.1170,124.0884,109.065$, and 91.0544) at levels of $5 \mathrm{ng}$ per injection. Fig. (4) gives five possible chemical structures for $\mathrm{C}_{16} \mathrm{H}_{14} \mathrm{O}_{4}$ and the molecular formulas, mass errors, and scores for the fragment ions that are shown in the QTOFMS spectrum in Fig. (3). Fragment ion at $\mathrm{m} / \mathrm{z} 193.0494$ corresponds to the loss of a phenyl group, and ion at $\mathrm{m} / \mathrm{z} 167.0334$ corresponds to the loss of $\mathrm{C}_{6} \mathrm{H}_{5}-\mathrm{CH}=\mathrm{CH}$ from the molecular ion making chemical structure B4 in Fig. (4) the most likely one. Fragment ions at $\mathrm{m} / \mathrm{z}$ $138.0310,110.0359$, and 95.0127, which correspond to $\mathrm{C}_{7} \mathrm{H}_{6} \mathrm{O}_{3}$, $\mathrm{C}_{6} \mathrm{H}_{6} \mathrm{O}_{2}$, and $\mathrm{C}_{5} \mathrm{H}_{3} \mathrm{O}_{2}$, respectively, support the dihydroxymethoxyphenyl-phenyl-propen-one. To establish by mass spectrometry the exact position of the various groups onto the phenyl ring, each of possible isomers need to be synthesized and their GC retention times and mass spectra need to be compared to those of Compound B. The MS/MS spectrum of Compound B generated from ion at $\mathrm{m} / \mathrm{z} 269.0806$ (see Fig. 3) exhibits in addition to the ions mentioned above a strong fragment ion at $m / z 226.0626\left(\mathrm{C}_{14} \mathrm{H}_{10} \mathrm{O}_{3}\right.$, mass error $0.6 \mathrm{ppm}$, score 99.6). This ion is due to a loss of $\mathrm{CO}$ from the ion at $\mathrm{m} / \mathrm{z} 254.0570$ $\left(\mathrm{C}_{15} \mathrm{H}_{10} \mathrm{O}_{4}\right.$, mass error $1.5 \mathrm{ppm}$, score 92.4$)$, which is formed by elimination of a $\mathrm{CH}_{3}$ group from the ion at $m / z 269.0802$.

\subsection{Identification of Compound $\mathrm{C}$}

Low-resolution MS spectrum of Compound C shown in Fig. (5) exhibits ions at $m / z 284,283,207,181,103$, and 77 and the molecular ion appears to be at $\mathrm{m} / \mathrm{z} 284$. The NIST library search gave at least one possible hit having molecular formula $\mathrm{C}_{17} \mathrm{H}_{16} \mathrm{O}_{4}$, which corresponds to hydroxy-dimethoxyphenyl-3phenyl-2-propen-1-one, also known as Flavokavin B. Compound C gives a very weak molecular ion at $\mathrm{m} / \mathrm{z} 284.1005$ but gives a strong (M-H) ion at $\mathrm{m} / \mathrm{z}$ 283.0959, which corresponds to $\mathrm{C}_{17} \mathrm{H}_{15} \mathrm{O}_{4}$ ( mass error $2.2 \mathrm{ppm}$, score 96.1). The fragment ion at $\mathrm{m} / z 207.0650\left(\mathrm{C}_{11} \mathrm{H}_{11} \mathrm{O}_{4}\right.$, mass error $0.7 \mathrm{ppm}$, score 95.7) corresponds to the loss of phenyl group from the molecular ion, and the fragment ion at $\mathrm{m} / \mathrm{z} 181.0507\left(\mathrm{C}_{9} \mathrm{H}_{9} \mathrm{O}_{4}\right.$, mass error $6.6 \mathrm{ppm}$, score 81.7) corresponds to the loss of $\mathrm{C}_{6} \mathrm{H}_{5^{-}}$ $\mathrm{CH}=\mathrm{CH}$ also from the molecular ion. A loss of $\mathrm{H}_{2} \mathrm{O}$ from the ion at $\mathrm{m} / \mathrm{z} 181.0507$ would account for ion at $\mathrm{m} / \mathrm{z} 163.0393$ $\left(\mathrm{C}_{9} \mathrm{H}_{7} \mathrm{O}_{3}\right.$, mass error $2.3 \mathrm{ppm}$, score 75.4$)$ and fragment ions at $\mathrm{m} / \mathrm{z} 77.0385$ and 137.0233 would correspond to $\mathrm{C}_{6} \mathrm{H}_{5}$ and $\mathrm{C}_{7} \mathrm{H}_{5} \mathrm{O}_{3}$, respectively. We therefore concluded that Compound $\mathrm{C}$ is possibly a hydroxy-dimethoxyphenyl-3-phenyl-2-propen-1one, similar to Flavokavin B, which was reported among the minor constituents of Kava by $\mathrm{He}$ et al [12]. However, to establish the exact position of the various groups onto the phenyl ring, each of possible isomers need to be synthesized and their GC retention times and mass spectra need to be compared to those of Compound $\mathrm{C}$. 


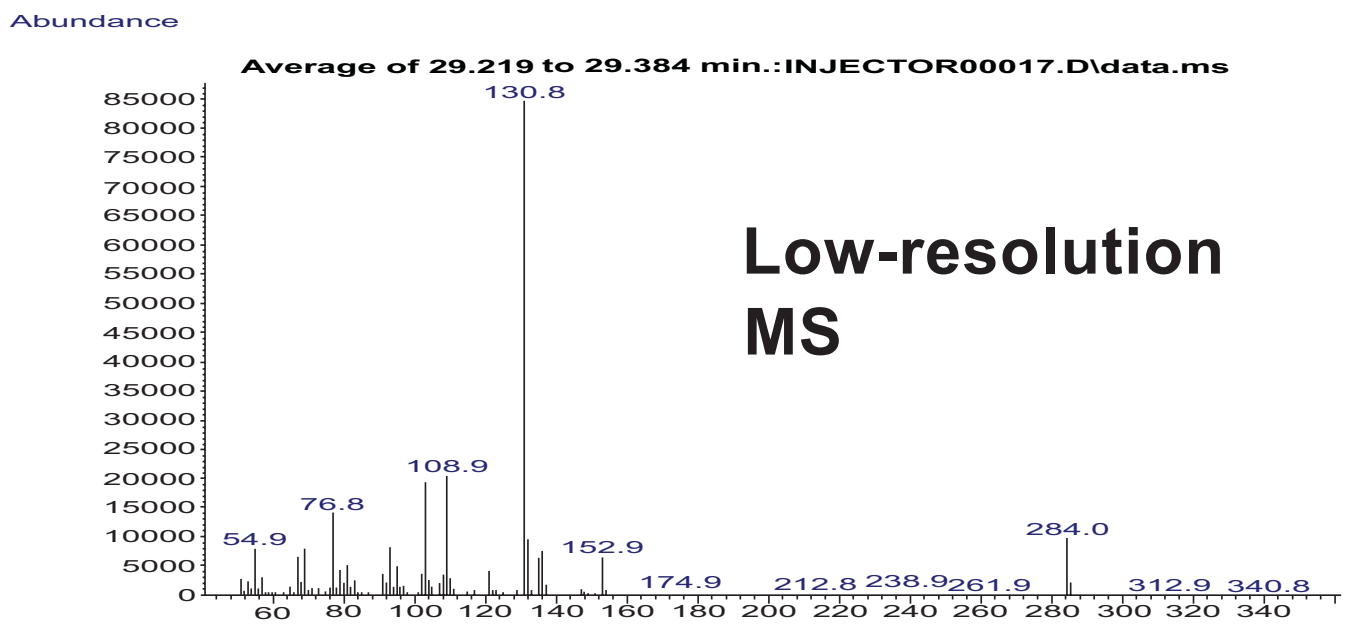
$m / z-->$
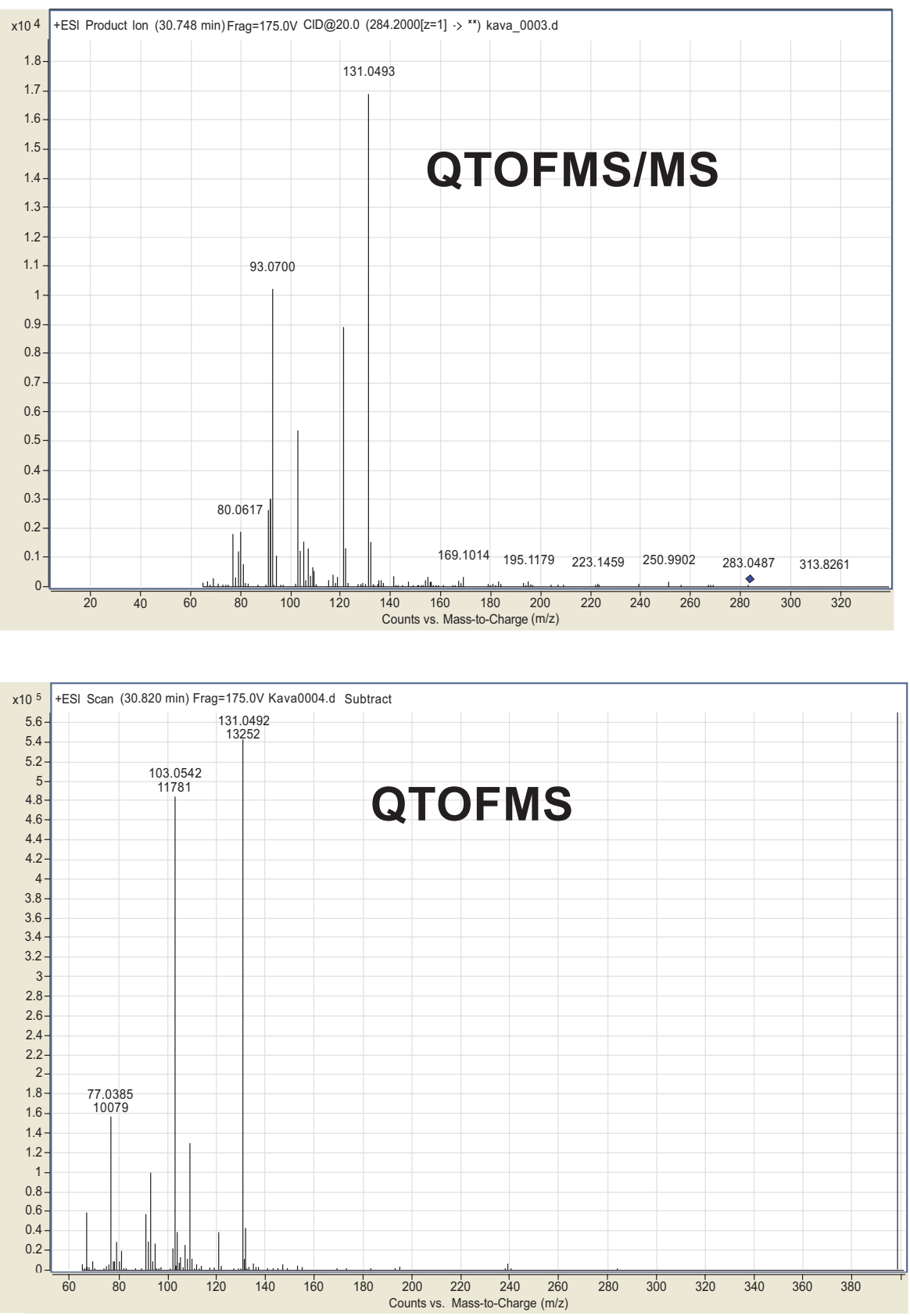

Fig. (2). Bornyl cinnamate (Compound A) $\mathrm{C}_{19} \mathrm{H}_{24} \mathrm{O}_{2} \mathrm{M}^{+} \cdot 284.1771$ (calc.) $\mathrm{M}^{+} \cdot 284.1754$ (experim.). 

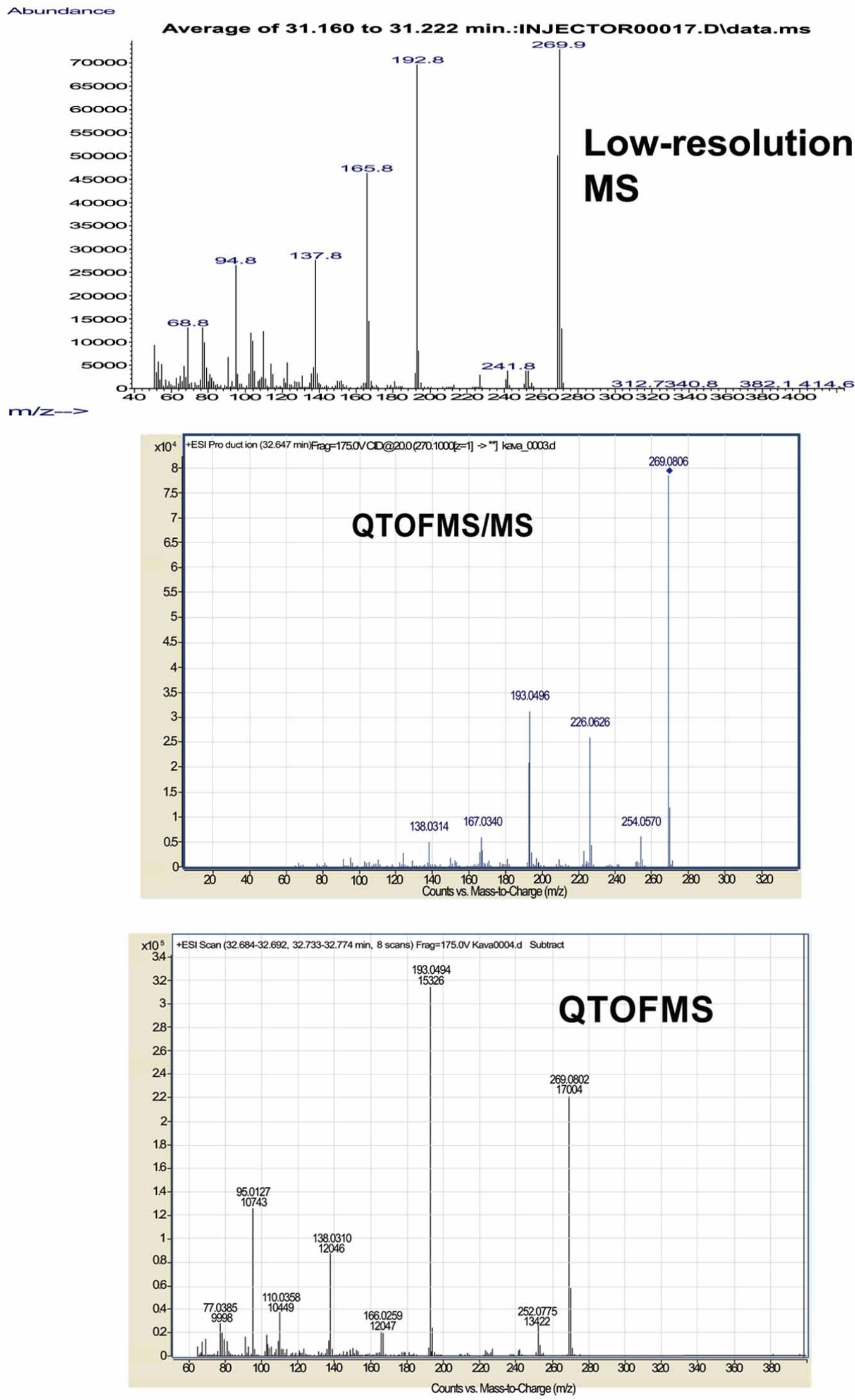

Fig. (3). Dihydroxy-methoxyphenyl-phenyl-propen-one (Compound B) $\mathrm{C}_{16} \mathrm{H}_{14} \mathrm{O}_{4} \mathrm{M}^{+} \cdot 270.0887$ (calc.) $\mathrm{M}^{+} \cdot 270.0874$ (experim.). 


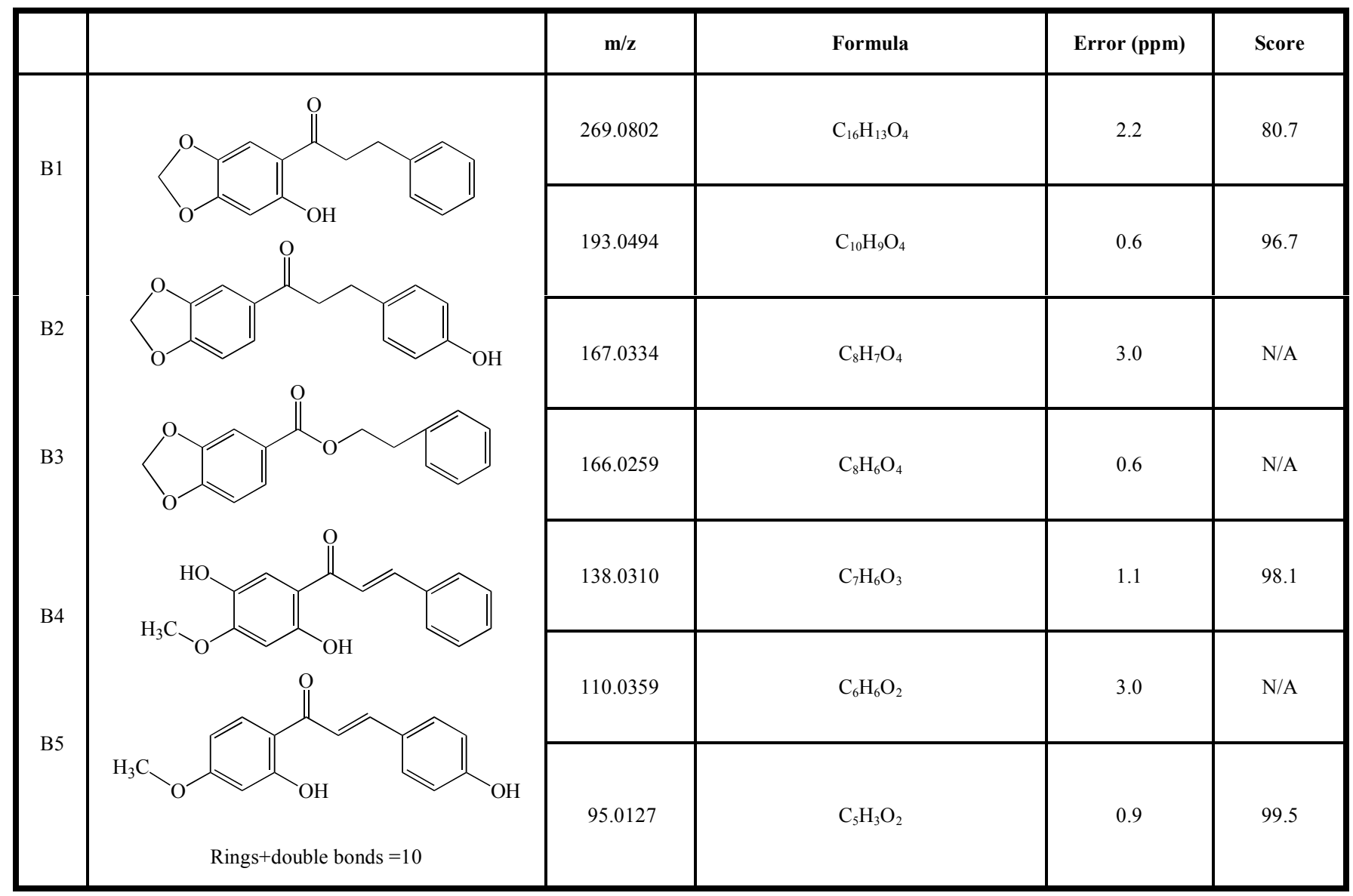

Fig. (4). Possible chemical structures for compound B.

\subsection{Identification of Compound D}

Low-resolution MS spectrum of Compound D shown in Fig. (6) exhibits ions at $\mathrm{m} / \mathrm{z} 314,313,207,181,180,152$, 134,121 , and 103, and the molecular ion appears to be at $m / z$ 314. The NIST library search gave three possible hits for this compound having molecular formulae $\mathrm{C}_{17} \mathrm{H}_{14} \mathrm{O}_{6}, \mathrm{C}_{18} \mathrm{H}_{18} \mathrm{O}_{5}$ and $\mathrm{C}_{22} \mathrm{H}_{34} \mathrm{O}$. The high resolution spectrum in Fig. (6) shows a strong ion at $\mathrm{m} / \mathrm{z} 313.1062$, which corresponds to $\mathrm{C}_{18} \mathrm{H}_{17} \mathrm{O}_{5}$, and an ion at $m / z 314.1109$, which would indicate that the molecular ion might be $\mathrm{C}_{18} \mathrm{H}_{18} \mathrm{O}_{5}$. The mass error for the $\mathrm{M}-\mathrm{H}$ ion was $2.5 \mathrm{ppm}$. The other molecular formulas above (i.e., $\mathrm{C}_{17} \mathrm{H}_{14} \mathrm{O}_{6}$ with $\mathrm{m} / z 314.0790$ and $\mathrm{C}_{22} \mathrm{H}_{34} \mathrm{O}$ with $\mathrm{m} / \mathrm{z}$ 314.2604) were eliminated from consideration because their mass errors were significantly higher than $3 \mathrm{ppm}$. There are several possible chemical structures for $\mathrm{C}_{18} \mathrm{H}_{18} \mathrm{O}_{5}$ (see Fig. 7). The fragment ion at $\mathrm{m} / \mathrm{z} 207.0644$ corresponds to a loss of $\mathrm{C}_{7} \mathrm{H}_{7} \mathrm{O}$ (methoxyphenyl group) from the molecular ion and the ion at $\mathrm{m} / \mathrm{z} 180.0419$ corresponds to the loss of $\mathrm{C}_{9} \mathrm{H}_{9} \mathrm{O}\left(\mathrm{CH}=\mathrm{CHC}_{6} \mathrm{H}_{5} \mathrm{OCH}_{3}\right)$. Further loss of $\mathrm{CO}$ from $\mathrm{C}_{9} \mathrm{H}_{9} \mathrm{O}$ results in ion at $\mathrm{m} / z 152.0459$ and a loss of $\mathrm{CH}_{3}$ from ion at $\mathrm{m} / z 152.0459$ results in ion at $\mathrm{m} / \mathrm{z} 137.0234$. The fragmentation of Compound $\mathrm{D}$ is very similar to Compound $\mathrm{C}$ and the ion at $\mathrm{m} / z 134.0726\left(\mathrm{C}_{9} \mathrm{H}_{10} \mathrm{O}\right)$ supports the fact that there is a methoxy group on the free aromatic ring attached to the $\mathrm{CH}=\mathrm{CH}$ bond. This compound is possibly a hydroxy-dimethoxyphenyl-3-methoxyphenyl-2-propen-1-one similar to Flavokavin A (compound D3 in Fig. 7), which was also reported to be present in small amounts in Kava [17]. Likewise for Compounds B and C, to establish by mass spectrometry the exact position of the various groups onto the phenyl rings, each of all possible isomers need to be synthesized and their GC retention times and mass spectra need to be compared to those of Compound D.

\section{CONCLUSIONS}

The identification of kava lactones by GC/QTOFMS was demonstrated. We believe this is the first use of a GC/QTOFMS to identify low-molecular weight compounds in herbal extracts by means of accurate mass measurements, isotope distributions, and $\mathrm{GC}$ retention times. Despite lack of standards to unequivocally confirm compound identities, the combination of accurate mass $(<3 \mathrm{ppm}$ average mass accuracy for molecular or quasi molecular ions), isotope abundance ratios, and resolution $>10,000$ provides a powerful analytical tool to help identify organic compounds in herbal extracts. Although we used both low- and highresolution MS in this study, the former will no longer be required once high-resolution MS is readily available.

\section{SUPPLEMENTARY MATERIAL}

This article also contains supplementary material and it can be viewed at www.bentham.org/open/toacj 

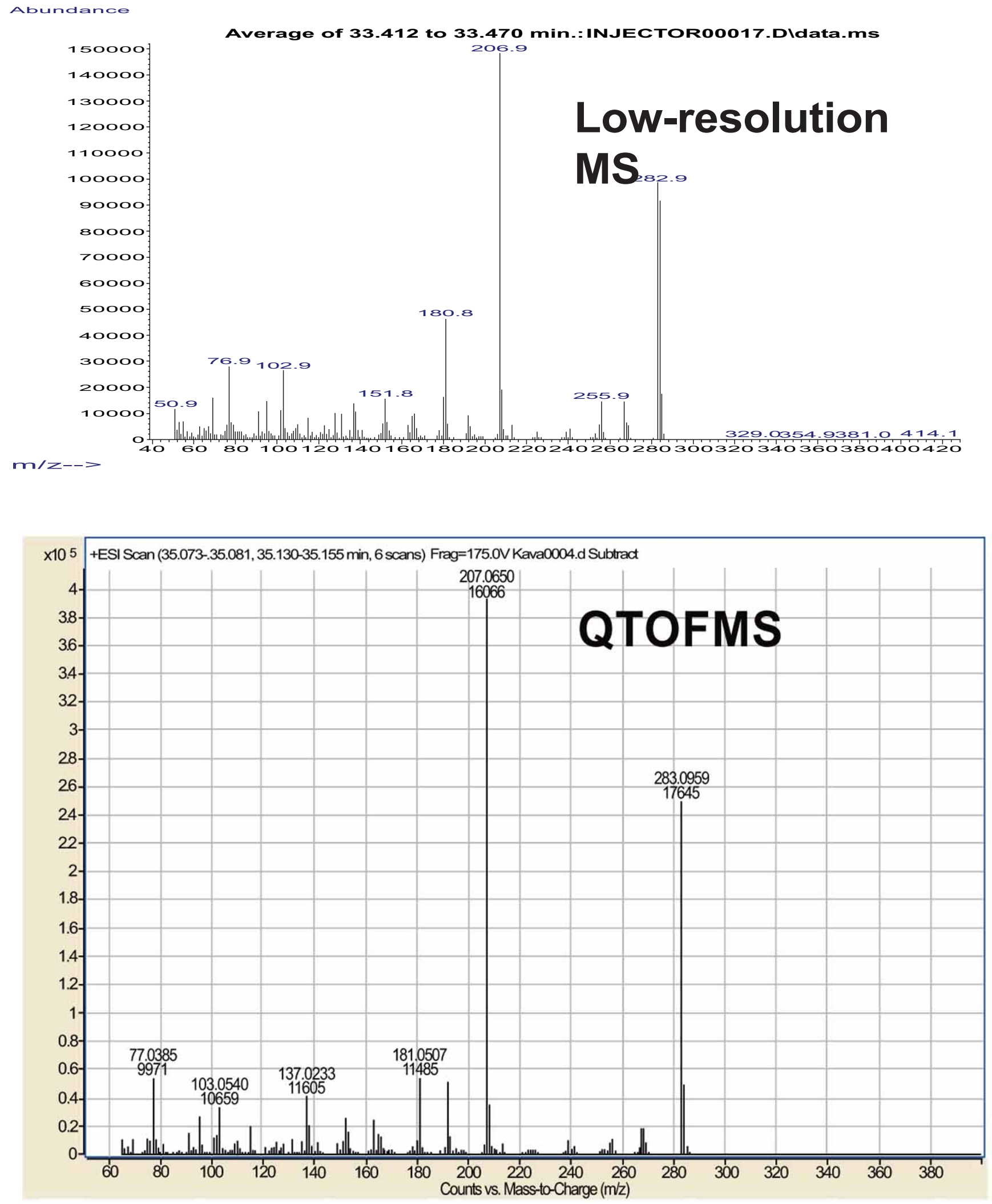

Fig. (5). Hydroxy-dimethoxyphenyl-3-phenyl-2-propen-1-one (Compound $\mathrm{C}) \mathrm{C}_{17} \mathrm{H}_{16} \mathrm{O}_{4} \quad(\mathrm{M}-\mathrm{H})^{+} 283.0965$ (calc.) (M-H) 283.0959 (experim.). 

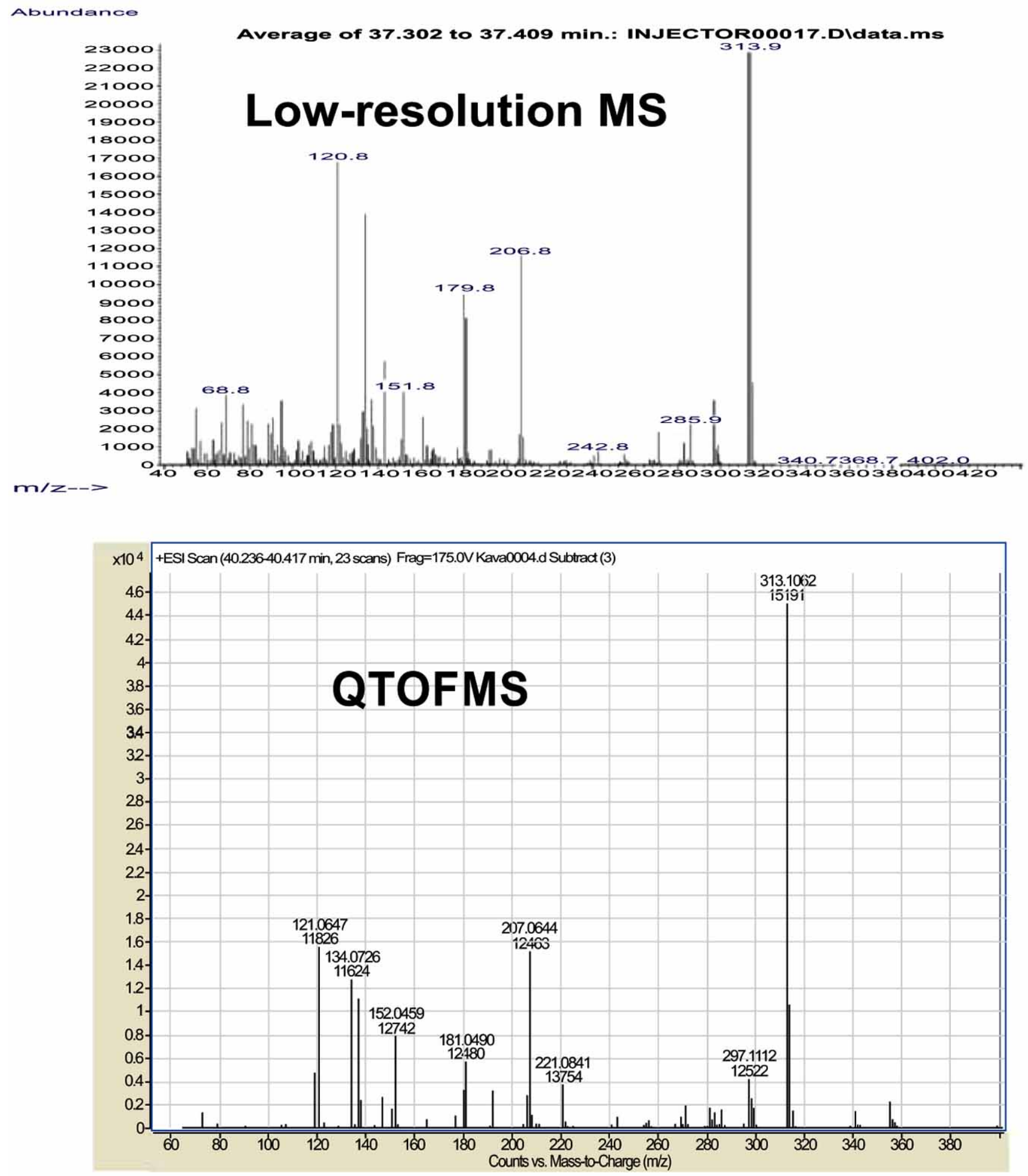

Fig. (6). Hydroxy-dimethoxyphenyl-3-methoxyphenyl-2-propen-1-one $\mathrm{C}_{18} \mathrm{H}_{18} \mathrm{O}_{5}$ (Compound D). (M-H) ${ }^{+} 313.1071$ (calc.) (M-H) 313.1062 (experim.). 


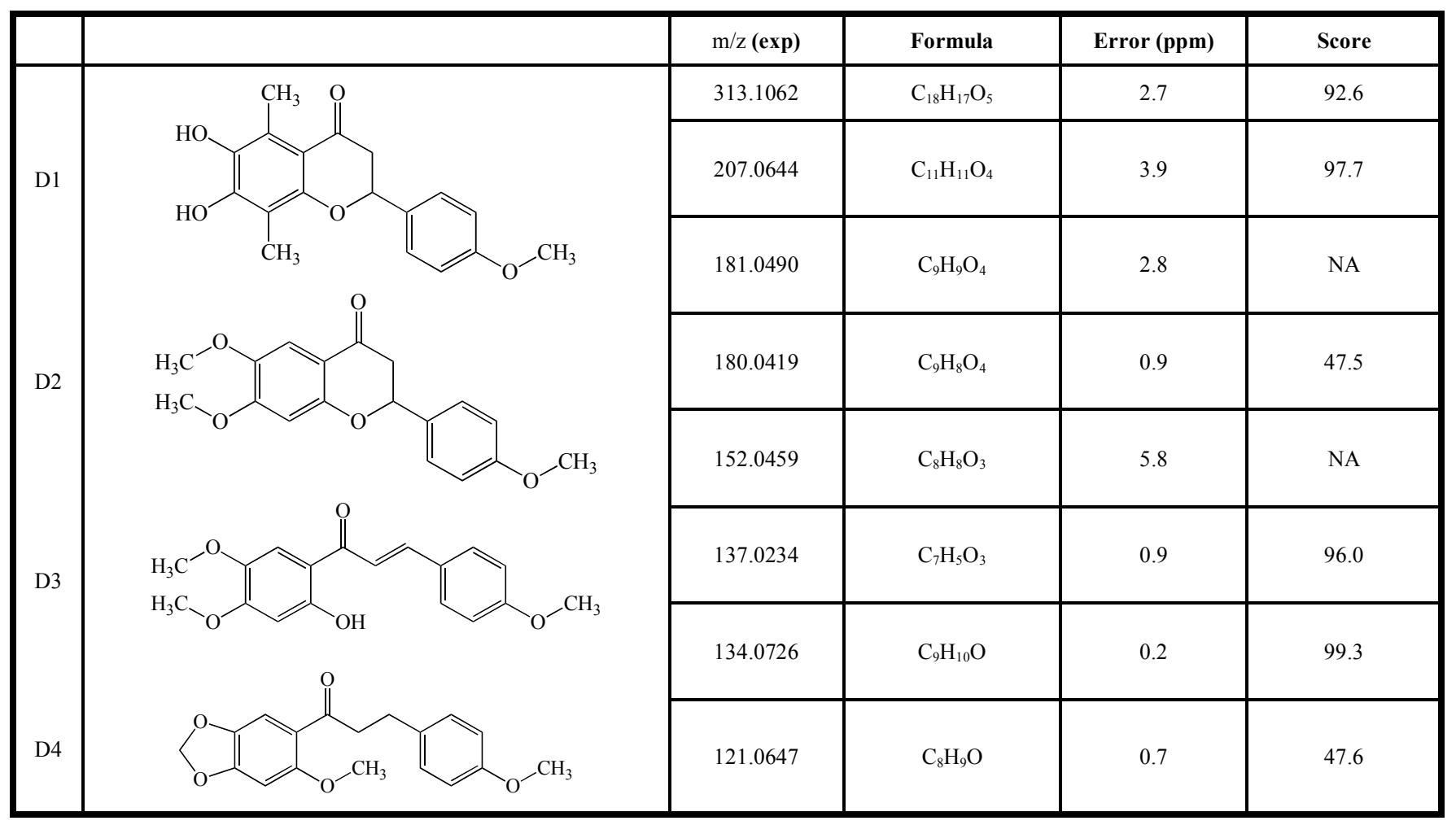

Fig. (7). Possible chemical structures for compound D.

\section{REFERENCES}

[1] Leung, A.Y.; Foster, S. Encyclopedia of Common Natural Ingredients; Wiley \& Sons: New York, 1996.

[2] Nerurkar, P.V.; Dragull, K.; Tang, C-S. In vitro toxicity of Kava alkaloid, pipermethystine, in HepG2 cells compared to Kava lactones. Toxicol. Sci., 2004, 79, 106-111.

[3] Lebot, V.; Merling, M.; Lindstrom, L. Kava the Pacific elixir The definitive guide to its ethnobotany, history, and chemistry; Yale University Press: New Haven, CT, 1992.

[4] Xuan, T.D.; Elzaawely, A.A.; Fukuta, M.; Tawata, S. Herbicidal and Fungicidal activities of lactones in kava (Piper methysticum). J. Agric. Food Chem., 2006, 54, 720-725.

[5] Wu, D.; Nair, M.G.; DeWitt, D.L. Novel compounds from Piper methysticum Forst (kava kava) roots and their effect of cyclooxygenase enzyme. J. Agric. Food Chem., 2002, 50, 701-705.

[6] Lopez-Avila, V.; Benedicto, J. Supercritical fluid extraction of Kava lactones from Piper methysticum (Kava) herb. J. High Resol. Chromatogr., 1997, 20, 555-559.

[7] Cheng, D.; Lidgard, R.O.; Duffield, P.H.; Duffield, A.M. Identification by methane chemical ionization gas chromatography/mass spectrometry of the products obtained by steam distillation and aqueous acid extraction of commercial Piper methysticum. Biomed. Environ. Mass Spectrom., 1988, 17, 371-376.

[8] Lechtenberg, M.; Quandt, B.; Schmidt, M.; Nahrstedt, A. Is the alkaloid pipermethystine connected with liver toxicity of kava products? Pharmazie, 2008, 63, 71-74.

[9] Dragull, K.; Yoshida, W.Y.; Tang, C-S. Piperidine alkaloids from Piper methysticum. Phytochemistry, 2003, 63, 193-198.
[10] Ganzera, M.; Khan, I.A. Analytical techniques for the determination of lactones in piper methysticum forst. Chromatographia, 1999, 50, 649653.

[11] Bobeldijk, I.; Boonzaaijer, G.; Spies-Faber, E.J.; Vaes, W.H.J. Determination of kava lactones in food supplements by liquid chromatographyatmospheric pressure chemical ionization tandem mass spectrometry. $J$. Chromatogr. A, 2005, 1067, 107-114.

[12] He, X.G.; Lin, L.Z.; Lian, L.Z. Electrospray high performance liquid chromatography - mass spectrometry in phytochemical analysis of kava (Piper methysticum) extract. Planta Med., 1997, 63, 70-74.

[13] He, X-G. On-line identification of phytochemical constituents in botanical extracts by combined high-performance liquid chromatographic-diode array detection-mass spectrometric techniques. J. Chromatogr. A, 2000, 880, 203-232.

[14] Lechtenberg, M.; Quandt, B.; Kohlenberg, F-J.; Nahrstedt, A. Qualitative and quantitative micellar electrokinetic chromatography of kava lactones from dry extracts of piper methysticum forst and commercial drugs. J. Chromatogr. A, 1999, 848, 457-464.

[15] Gautz, L.D.; Kaufusi, P.; Jackson, M.C.; Bittenbender, H.C.; Tang, C-S Determination of kavalactones in dried kava (Piper methysticum) powder using near-infrared reflectance spectroscopy and partial leastsquares regression. J. Agric. Food Chem., 2006, 54, 6147-6152.

[16] Warburton, E.; Bristow, A. Fourier transform ion cyclotron resonance mass spectrometry for the characterization of kavalactones in the kava plant: elemental formulae confirmation by dual spray accurate mass measurement and structural confirmation by infrared multiphoton dissociation and sustained off-resonance irradiation collision induced dissociation. Eur. J. Mass Spectrom., 2006, 12, 223-233.

[17] Bilia, A.R.; Scalise, L.; Bergonzi, M.C.; Vincieri, F.F. Analysis of Kava lactones from Piper methysticum (kava-kava). J. Chromatogr. B, 2004, $812,203-214$

(C) Lopez-Avila and Yefchak; Licensee Bentham Open

This is an open access article licensed under the terms of the Creative Commons Attribution Non-Commercial License (http://creativecommons.org/licenses/by-nc/ $3.0 /$ ) which permits unrestricted, non-commercial use, distribution and reproduction in any medium, provided the work is properly cited. 